\title{
THE EFFECTIVENESS OF FORMING BREASTFEEDING SUPPORT GROUP PROGRAMS TO IMPROVE EXCLUSIVE BREASTFEEDING
}

\author{
Efektivitas Pembentukan Program Kelompok Pendukung ASI \\ untuk Meningkatkan ASI Eksklusif
}

\begin{abstract}
*Dewi Roudhotul Hasanah1, Nuzulul Kusuma Putri', Andini Yulina Pramono
${ }^{1}$ Department of Health Policy and Administration, Faculty of Public Health, Universitas Airlangga, Indonesia ${ }^{2}$ Department of Health Services Research and Policy Research School of Population Health, College of Health and Medicine, Australia National University, Australia

*Correspondence: dewi.roudhotul.hasanah-2015@fkm.unair.ac.id
\end{abstract}

\begin{abstract}
Background: Child and maternal health in Indonesia can be improved by promoting the practice of exclusive breastfeeding, which can be done through the formation of breastfeeding support groups. The villages of Sugihwaras and Sumbergede have initiated breastfeeding support groups; however, the two villages differ in the framework of their programs and their intervention methods for pregnant and breastfeeding mothers.

Aim: This paper analyzes the effectiveness of support groups in these two villages to improve the rate of exclusive breastfeeding.

Methods: Using a case study approach, a comparative analysis was done using a total sampling technique and descriptive analysis. Samples were selected from the Fieldwork Report of Groups 14 and 15, Faculty of Public Health, University Airlangga from 2017 to 2018, and the study compared the community's characteristics (as input), program management (as process), and results in forming breastfeeding support groups (as output)

Results: The two villages had similar community characteristics, and the average duration of each program was the same. Sumbergede focused on forming a framework of support for the breastfeeding support group, while Sugihwaras focused on breastfeeding mothers and their husbands. Indicator analysis of the program showed that Sumbergede ( $80 \%$ achieved) had a $5.71 \%$ higher percentage of attainment compared to Sugihwaras $(85.71 \%$ achieved). Analysis of the program's strengths and weaknesses showed that Sumbergede had more success and power in resources in its region.

Conclusion: The intervention program in Sumbergede was more effective. It has a greater potential to be a sustainable program that will achieve a $100 \%$ rate of exclusive breastfeeding within the next year.
\end{abstract}

Keywords: breastfeeding support group, exclusive breastfeeding, intervention, effectiveness.

\section{ABSTRAK}

Latar Belakang: ASI Eksklusif merupakan isu kesehatan ibu dan anak di Indonesia. Dengan Kelompok Pendukung ASI (KP-ASI), ASI ekslusif diharapkan dapat ditingkatkan. Desa Sugihwaras dan Desa Sumbergede merupakan dua desa yang sedang mewujudkan program KP-ASI. Namun, perumusan program pembentukan KP-ASI dan bentuk atau metode pemberian intervensi pada ibu hamil dan ibu menyusui di kedua desa tersebut berbeda.

Tujuan: Untuk menganalisis keefektifan program pembentukan KP-ASI dan pelaksanaan program intervensi pada ibu hamil dan menyusui dalam meningkatkan perilaku ASI Eksklusif di Desa Sugihwaras dan Sumbergede. Metode: Penelitian ini menggunakan pendekatan studi case terhadap dua program pembentukan KP-ASI. Analisis perbandingan dilakukan secara deskriptif dengan pengambilan sampel dari data Laporan Praktik Kerja Lapangan (PKL) Kelompok 14 dan 15 Tahun Akademik 2017/2018, Fakultas Kesehatan Masyarakat, Universitas Airlangga. Penelitian ini menggunakan teknik total samplng dan analisis deskriptif dengan membandingkan karakteristik masyarakat (input), bentuk intervensi dan pengelolaan program (proses), dan hasil evaluasi pembetukan KP-ASI (output).

Hasil: Karakteristik masyarakat cenderung sama, dan rata-rata durasi program kedua desa sama. Desa Sumbergede berfokus pada kesiapan program pembentukan kader KP-ASI, Desa Sugihwaras berfokus pada ibu menyusui dan suami. Analisis indikator keberhasilan program menyatakan Desa Sumbergede memiliki persentase ketercapaian 5,71\% lebih tinggi. Analisis kelebihan dan kekurangan program menemukan Desa Sumbergede lebih berhasil dan memiliki keunggulan pada sumber daya di wilayahnya. 
Kesimpulan: Program intervensi di Desa Sumbergede cenderung lebih efektif. Program intervensi tersebut memiliki potensi yang lebih besar untuk menjadi program yang berkelanjutan pada tahun berikutnya untuk meningkatkan $100 \%$ ASI Eksklusif.

Kata kunci: Kelompok Pendukung ASI, ASI Eksklusif, intervensi, efektivitas.

\section{INTRODUCTION}

The second of the United Nations' Sustainable Development Goals (SDGs) focuses on ending hunger, achieving better food security, improving nutrition, and promoting sustainable agriculture. Health sectors should ensure that babies have a sufficient quantity of safe and nutritious food throughout the year. The principles of this goal have been embedded in Indonesia's First 1,000 Days of Life program, which gives infants the opportunity for a lifetime of better health (Cusick and Georgieff, no date). During this period, humans experience their most rapid rate of growth, and adequate nutrition is essential for babies and mothers, which can best be achieved by breastfeeding (Indonesian Republic Government, 2012).

Exclusive breastfeeding is defined as providing breastmilk for infants in the first six months without adding and/or substituting other foods or drinks. The Indonesian Healthy Family Approach in 2016, compiled by the Ministry of Health, stated that exclusive breastfeeding for infants (from birth to six months) is an indicator of a healthy family. The World Health Organization (WHO) also recommends that all infants should be exclusively breastfed from birth to six months of age. After that, children should receive supplemental foods but continue to breastfeed for at least two years (Indonesian Ministry of Health, 2016).

The 2016 Breastfeeding Series produced by The Lancet showed that exclusive breastfeeding could decrease mortality from infections by $88 \%$ worldwide in infants under age three. It also showed that $31.36 \%$ to $37.94 \%$ of children became sick because they did not exclusively breastfeed (Hajeebhoy, 2016). In several Indonesian regions, however, the rate of exclusive breastfeeding is still inadequate.

The 2017 Bojonegoro District Health Profile Data showed that the rate of exclusive breastfeeding had decreased during the previous two years: $89.4 \%$ in 2015 and $88.2 \%$ in 2016 . Likewise, the rate of exclusive breastfeeding in the Nglumber Primary Healthcare Center in the Kepoh Baru subdistrict reached only $70.3 \%$ (Bojonegoro District Health Office, 2017).

The Nglumber Primary Healthcare Center is a first-level primary health facility responsible for public health in its region. This includes two villages that had not reached a $100 \%$ rate of exclusive breastfeeding: Sumbergede and Sugihwaras; these are two of the 25 villages in the Kepoh Baru subdistrict, and Sugihwaras is located to the east of Sumbergede.

Both internal and external factors have prevented these villages from reaching the desired breastfeeding goals. The internal factors include the mother's knowledge about breastfeeding, her level of education, the family's employment status, and their socioeconomic conditions. The external factors include the availability of health care facilities, the work environment, and the community and family closest to the mother. The family's importance as a motivating factor for the mother is often overlooked (Februhartanty et al., 2012). Encouragement and physical support during breastfeeding determine the success of achieving the goal of exclusive breastfeeding. The family, especially the husband, influences the mother's emotional well-being and fosters a sense of 
self-confidence. Thus, mothers with this support are more enthusiastic and consistent in providing exclusive breastfeeding for their babies. The source of motivation, however, cannot just come from family but also depends on the wider community (Raffle et al., 2011).

Access to a breastfeeding support group is also known to be one of the ten steps to successful breastfeeding, according to the WHO (2019). A breastfeeding support group is formed by 6 to 12 pregnant women and new mothers who hold regular in-home meetings. The group exchanges experiences, discusses challenges, and provides mutual support related to maternal and child health, especially pregnancy, breastfeeding, and nutritional fulfillment. Breastfeeding support groups are created specifically for mothers who want to initiate breastfeeding at birth and continue it exclusively for six months; after six months, breastfeeding continues but is supplemented with other food.

The Indonesian Ministry of Women Empowerment and Child Protection stated that breastfeeding support groups should be formed by community health facilities to support pregnant women, new mothers, and caregivers. Breastfeeding support groups can include breastfeeding mothers, husbands, families, community leaders, and religious leaders.

Groups in health-care facilities also include professional staff (the Ministry of Women Empowerment and Child Protection, 2010).

Breastfeeding support groups are vital because mothers will have a sense of being supported, cared for, and loved. This creates positive emotions that will increase the mother's oxytocin hormones and subsequent milk production. Breastfeeding support groups encourage pregnant women to have the confidence to breastfeed (Yunianti, Rofi'ah, and Rubiyanti, 2017). Breastfeeding mothers can gain knowledge and learn from the experiences of other breastfeeding mothers; thus, babies will get the best food and nutrition from birth. The motivation of husbands and family members is also needed to ensure the success of breastfeeding, as are the health-care workers who provide support for the group members (Yunianti, Rofi'ah, and Rubiyanti, 2017).

Breastfeeding support groups
provide more opportunities for
breastfeeding mothers to actively participate in health promotion and education. Education can come through one-way methods such as counseling, workshops, and pamphlets given to the mother. Breastfeeding support groups, however, provide a two-way exchange of information, and the advice and sharing of each participant's knowledge and experience help the other breastfeeding mothers to overcome obstacles and constraints.

A study about breastfeeding support groups at Wonoayu Primary Healthcare Center in Sidoarjo City found that mothers who participated in the groups were 3.7 times more likely to breastfeed exclusively compared to the mothers who did not participate (Wati and Muniroh, 2018). In another study, at the Kasihan Primary Healthcare Center in the Working Area II of Bantu, there was a significant $72.4 \%$ relationship between participation in a breastfeeding support group and the success of exclusive breastfeeding for infants aged six to nine months (Purwanti, 2015). According to research conducted by Nurrohmah, Prawitasari, and Nisman (2015), a mother's participation in a breastfeeding support group significantly affected exclusive breastfeeding behavior, which was 12.85 times higher than in women who did not participate. Support from husbands and the wider social structure also affected exclusive breastfeeding behavior (Nurrohmah, Prawitasari, and Nisman, 2015). 
In line with this past research, the villages of Sugihwaras and Sumbergede created a program of breastfeeding support groups that sought to increase the mothers' motivation to breastfeed during the crucial period from birth to six months.

Although two villages might have the same challenges and causal factors, this study showed that interventions might be different based on local culture, the capabilities of the community, the capacity of those who intervene, the availability of support facilities, and other factors.

Midwives led the breastfeeding support groups, and the villages recruited volunteers to assist in the effort.

Although the support groups used different methods, this study sought to compare which forms of interventions or programs were more effective and had the potential to be continued in subsequent years. The results could provide suggestions and influence decision-making for villages that share Sugihwaras and Sumbergede's characteristics and challenges.

\section{METHODS}

A case study approach was used to analyze breastfeeding support group programs. It compared interventions, education, and actions within the community to maintain breastfeeding support groups that would improve exclusive breastfeeding behavior.

The subjects were selected from two villages in the Kepoh Baru Subdistrict, Bojonegoro District (the villages of Sugihwaras and Sumbergede. The sampling came from data compiled in the Field Work Report of Groups 14 and 15, from 2017 to 2018, by students from the Faculty of Public Health, University Airlangga.

The inclusion criteria selected women with a child less than two years old who participated in a breastfeeding support group reinforced by volunteers, community leaders, and the village's government. The selected sample size used total sampling, and there were 74 samples from both villages.

A descriptive analysis compared the community's characteristics (as input), the forms of intervention or program (as a process), and the attainment of the program's success (as an output). The community's characteristics and forms of intervention were independent variables, while the effectiveness of the breastfeeding support group program was a dependent variable.

To simplify the analysis, the participants in Sugihwaras were assigned to Group A, while the Sumbergede participants were placed in Group B. The potential sustainability of the support group formation was based on the most effective analysis. Indicators that determined the effectiveness of the program could be obtained by calculating the percentage of success based on evaluating each intervention or program and comparing the strengths and weaknesses of each program.

\section{RESULTS AND DISCUSSION}

\section{Community Characteristics}

The adjoining villages of Sugihwaras and Sumbergede had relatively similar community characteristics when education, work, culture, overall health status, and medical challenges were compared. Understanding the community's characteristics was essential and had to be correctly performed by the researchers to gauge the intervention. The communities' conditions, capacities, strengths, values, and norms are shown in Table 1.

Fifty percent of respondents had a junior high school or high school certificate, but the overall education level was relatively low, with only $11 \%$ of the 
community having graduated from higher education.

Most people were middle-class and worked as farmers, farm laborers, and employees of private companies.

Each town had roughly equal numbers of men compared to women.

A study showed that sociodemographic and psycho-social characteristics positively influence the duration of breastfeeding (Bosnjak et al., 2009). These characteristics include when the decision to breastfeed was made, the intended duration of breastfeeding, the household income, and the smoking habits of the mother during pregnancy. Mothers who breastfed just after birth and who attended breastfeeding support groups would most often breastfeed for at least six months. Mothers breastfed for longer than six months if they had a higher monthly household income and did not smoke during pregnancy (Bosnjak et al., 2009).

\section{Analysis of Intervention Programs}

Many women are provided with education and counseling to promote exclusive breastfeeding, but these methods do not improve the rate and length of breastfeeding. Breastfeeding mothers need skills and support from their peers to give them trust, acceptance, recognition, and appreciation. The most effective support comes from peer groups that share the same experience and community characteristics (Susilo, Kurdant, and Siswati, 2012).
To achieve the exclusive breastfeeding coverage, both groups conducted a breastfeeding program in Sugihwaras and Sumbergede. Two programs were created that were each informed by different theories for breastfeeding support. Both villages have several activities in one program. Table 2 shows the differences between the breastfeeding support programs assigned to Groups A and B.

The number of activities in each group was carried out in a 4:3 ratio, meaning that the interventions given to Group A were more intensive than those given to Group B. Due to the intensity of meeting, Group A met four times per month, while Group B met only three times. The average duration of the activities in Group A was two hours and 15 minutes, while Group B had an average duration of two hours and 20 minutes.

Interventions in both groups provided health promotion and education with the end result of promoting exclusive breastfeeding. They both had the same targets: pregnant and breastfeeding mothers and their husbands. However, the target of Group A comes from immunization volunteers who also get involved in breastfeeding support group since the Group A does not have enough incentives for additional volunteers. Thus, these volunteers accompany pregnant women and breastfeeding mothers in the breastfeeding program.

Table 1. Comparative Analysis of Community Characteristics in Group A and Group B.

\begin{tabular}{lrc}
\hline \multicolumn{1}{c}{ Comparison Variables } & \multicolumn{2}{c}{ (\%) } \\
\cline { 2 - 3 } Education level & Group A & Group B \\
- Senior High School & $31.36 \%$ & $60.56 \%$ \\
- Junior High School & $42.46 \%$ & $17.91 \%$ \\
- Elementary School & $17.76 \%$ & $11.10 \%$ \\
- Others & $8.42 \%$ & $10.43 \%$ \\
\hline
\end{tabular}




\begin{tabular}{|c|c|c|}
\hline 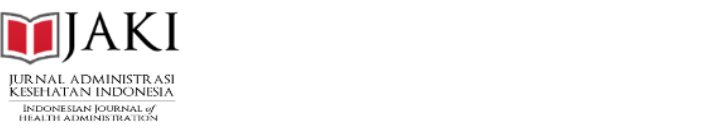 & \multicolumn{2}{|c|}{$\begin{array}{r}\text { Jurnal Administrasi Kesehatan Indonesia Volume } 8 \text { No } 1 \text { June } 2020 \\
\text { Published by Universitas Airlangga } \\
\text { Doi: 10.20473/jaki.v8i1.2020.5-19 }\end{array}$} \\
\hline \multicolumn{3}{|l|}{ Work type } \\
\hline - Farmers & $44.93 \%$ & $33.13 \%$ \\
\hline - Farm laborers & $19.91 \%$ & $13,00 \%$ \\
\hline - Employees of private companies & $12.51 \%$ & $13.09 \%$ \\
\hline - Small and medium level of enterprises & $6.93 \%$ & $00.00 \%$ \\
\hline - Others & $15.72 \%$ & $4.62 \%$ \\
\hline - Indeterminate work & $00.00 \%$ & $36.16 \%$ \\
\hline \multicolumn{3}{|l|}{ Gender distribution } \\
\hline- Men & $49.00 \%$ & $50.95 \%$ \\
\hline - Women & $50.67 \%$ & $49.03 \%$ \\
\hline
\end{tabular}

Source: Field Work Practice Report (14\&15 group) 2017/2018, Faculty of Public Health, Universitas Airlangga

The frameworks for activities in the two groups were different: Group A conducted a workshop, while Group B held a sharing session. The workshop was more scientific and serious, while the sharing session was more flexible and conveyed the speakers' personal experiences. The programs had a different duration of activities, and the workshops conducted by Group A had richer information compared to the sharing session. The workshops covered a particular theory related to the benefits of exclusive breastfeeding: the ideal way to breastfeed, the introduction of breastmilk pumps, and the proper way to express breastmilk. The introduction of the breastmilk pump provided alternatives for working mothers who breastfeed. Effectiveness of giving breastmilk pumps as rewards has not been unproven yet. Using breastmilk pumps increased the number of mothers who expressed breastmilk (Crossland et al., 2016); Mothers who work are often unable to provide exclusive breastfeeding to their children.

The success of the information provided in the activities was evaluated based on the results of a pre-test and posttest. Using media for conducting activities in each group indicates that Group A was more skilled in delivering information to the participants; by using more varied media, the participants were more receptive to the conveyed information. Media that clearly and directly described the right implementation of the information were beneficial for participants, and thus they did not need to imagine how to implement the information into daily life. In Activity II, both groups used an individual approach through a home visit.

Participants in the program included families, the closest people to the breastfeeding mothers, and community groups that motivated breastfeeding. Although the names and concepts of Activity II for each group were different, the activities had the same goal: to enhance support from the social environment around the breastfeeding mothers. For example, people in the mothers' environment may increase the mothers' self-confidence to carry out exclusive breastfeeding until their babies were six months old.

In the study "The effect of breastfeeding exclusive training on knowledge in breastfeeding support groups," there was a significant increase in mothers' knowledge $(p<0.05)$ before and after training and formation of breastfeeding support groups in Mekargalih and Cipacing villages in the Jatinangor subdistrict. Hence, the formation and training of a breastfeeding support group can encourage mothers to adhere to exclusive breastfeeding (Sri, Judistiani, and Indra, 2016). 
Table 2. Analysis of the Intervention Program in Groups A and B

Intervention Program

\begin{tabular}{|c|c|}
\hline Group A & Group B \\
\hline $\begin{array}{l}\text { Activity I } \\
\text { "Get Ready to be Exclusive Breastfeeding } \\
\text { Village" Workshop (Workshop SIAP DESASI) } \\
\text { - Description: activities run by signing an } \\
\text { approval petition of SIAP DESASI program, } \\
\text { conducting a pre-test and post-test, transfer } \\
\text { of information, demonstration of ideal } \\
\text { breastfeeding procedures, question-answer } \\
\text { sessions } \\
\text { - Target: pregnant women, breastfeeding } \\
\text { mothers } \\
\text { - Media: public service advertisements, baby } \\
\text { mannequins, petition banner } \\
\text { - Topic: exclusive breastfeeding, benefits of } \\
\text { breastfeeding for mothers and babies, } \\
\text { breastfeeding support groups, socialization } \\
\text { of ideal breastfeeding procedures and } \\
\text { breastmilk pumps } \\
\text { - Pre-test and post-test (a decrease of } 8 \% \text { in } \\
\text { the high-value category) } \\
\text { - Duration: three hours } \\
\text { - Cost: IDR } 1,193,500\end{array}$ & $\begin{array}{l}\text { Activity I } \\
\text { Exclusive Breastfeeding Fun Sharing } \\
\text { Session (Sharing session TALK SIK } \\
\text { ASIEK) } \\
\text { - Description: activities are in a sharing } \\
\text { sessionformat to show the importance } \\
\text { of exclusive breastfeeding and share } \\
\text { questions and answers with } \\
\text { educational videos } \\
\text { - Target: fertile couples } \\
\text { - } \text { Media: public service advertisements } \\
\text { - } \text { Topic: exclusive breastfeeding, } \\
\text { nutrition fulfillment for mothers, } \\
\text { benefits of exclusive breastfeeding for } \\
\text { fertile couples } \\
\text { - Pre-test and post-test (an increase of } \\
\text { 18.75\% in behavior) } \\
\text { - Duration: two hours } \\
\text { - Cost: IDR } 484,000\end{array}$ \\
\hline $\begin{array}{l}\text { Activity II } \\
\text { One fun day with a breastfeeding support } \\
\text { group } \\
\text { - Description: a one-day session is done by } \\
\text { reviewing previous workshops, giving a } \\
\text { calendar to participants, and taking a } \\
\text { testimonial video } \\
\text { - Target: breastfeeding mothers (with infants } \\
\text { from birth to six months) } \\
\text { - Media: electronic posters, an exclusive } \\
\text { breastfeeding calendar } \\
\text { - Activities: socializing the roles of the } \\
\text { breastfeeding support group, distributing } \\
\text { calendars for checking the frequency of } \\
\text { everyday breastfeeding, and taking videos of } \\
\text { declaration support } \\
\text { - Method: a home visit } \\
\text { - Duration: two hours } \\
\text { - Cost: IDR 750,000 }\end{array}$ & $\begin{array}{l}\text { Activity II } \\
\text { Exclusive breastfeeding support group } \\
\text { Session I (Keping/Kelompok } \\
\text { Pendamping I) } \\
\text { - Description: activities are conducted } \\
\text { by forming, assisting, and socializing } \\
\text { the exclusive breastfeeding volunteers } \\
\text { - Targets: immunization volunteers, } \\
\text { exclusive breastfeeding volunteers, } \\
\text { village municipality abo modules, and } \\
\text { - Media: guidebooks, exclusive } \\
\text { pocketbooks about form of } \\
\text { breastfeeding, letters of support from } \\
\text { the Village Head (a form } \\
\text { commitment) the } \\
\text { - Activities: socializing } \\
\text { breastfeeding support group, forming } \\
\text { a structure of exclusive breastfeeding } \\
\text { volunteers, and writing letters of } \\
\text { support for the breastfeeding support } \\
\text { group program } \\
\text { Method: socialization and sharing }\end{array}$ \\
\hline
\end{tabular}




\begin{tabular}{|c|c|}
\hline 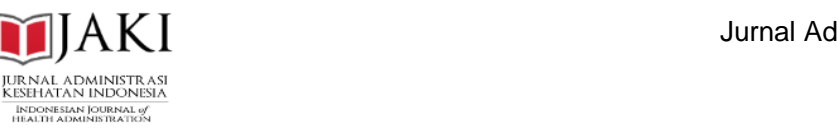 & $\begin{array}{r}\text { inistrasi Kesehatan Indonesia Volume } 8 \text { No } 1 \text { June } 2020 \\
\text { Published by Universitas Airlangga } \\
\text { Doi: } 10.20473 / \text { jaki.v8i1.2020.5-19 }\end{array}$ \\
\hline \multicolumn{2}{|c|}{ Intervention Program } \\
\hline Group A & Group B \\
\hline & $\begin{array}{l}\text { - Duration: two hours } \\
\text { - } \text { Cost: IDR 109,750 }\end{array}$ \\
\hline Activity III & Activity III \\
\hline Monitoring and Evaluation & Exclusive breastfeeding support group \\
\hline $\begin{array}{l}\text { - Description: activities are done by monitoring } \\
\text { an activity calendar (frequency of } \\
\text { breastfeeding) and giving stickers as a } \\
\text { reward }\end{array}$ & $\begin{array}{l}\text { Session II (Keping/Kelompok } \\
\text { Pendamping II) } \\
\text { - Description: an activity to monitor and } \\
\text { evaluate with targeted volunteers and }\end{array}$ \\
\hline $\begin{array}{l}\text { - Target: breastfeeding mothers with babies } \\
\text { from birth to six months old } \\
\text { - Media: exclusive breastfeeding stickers } \\
\text { - Activities: monitoring a weeklong checklist of } \\
\text { breastfeeding frequency per day on a }\end{array}$ & $\begin{array}{l}\text { mothers by home visits } \\
\text { - Targets: pregnant women in the } \\
\text { second trimester and breastfeeding } \\
\text { mothers with babies from birth to six } \\
\text { months old }\end{array}$ \\
\hline $\begin{array}{l}\text { breastfeeding calendar, sharing challenges } \\
\text { to breastfeeding, and giving appreciation }\end{array}$ & $\begin{array}{l}\text { - Media: exclusive breastfeeding } \\
\text { guidebook }\end{array}$ \\
\hline $\begin{array}{l}\text { stickers to families who have successfully } \\
\text { implemented exclusive breastfeeding for a } \\
\text { week }\end{array}$ & $\begin{array}{l}\text { - Activities: monitoring and controlling } \\
\text { the frequency of breastfeeding and } \\
\text { filling pocketbooks by breastfeeding }\end{array}$ \\
\hline - Method: home visit & support group volunteers \\
\hline - Duration: two times a week for one week (two & - Method: home visit \\
\hline hours per meeting) & - Dura \\
\hline - Cost: IDR 50,000 & - Cost: IDR 380,300 \\
\hline
\end{tabular}

Activity II in Group B was more concrete because it directly involved representatives from the village government. To show support and commitment to the program, the village head was present and signed a letter of agreement to recruit breastfeeding volunteers and to form the management structure. In Group I, the village government took part in the activities, providing more support compared to Group II activities that only involved the community.

The involvement of the village government showed that they understood the health challenges, for which the village government had responsibility along with the health workers. The Indonesia Government Regulation No. 33 of 2012 required village governments to implement a national policy on exclusive breastfeeding; carry out advocacy and

The Effectiveness of... socialization; provide technical training; and foster, monitor, evaluate, and supervise the implementation of exclusive breastfeeding programs in health service facilities, health education units, workplaces, public facilities, and the community. The village government carried out the duties of the district government at the village level.

Activity II in Group A only involved the primary targets (breastfeeding mothers) and secondary targets (their families). The breastfeeding support groups provided information to help the family motivate the mothers during the breastfeeding period.

Group B used more media for Activity II, such as a guidebook, module, and pocketbook for the breastfeeding support group volunteers, and a letter of agreement on forming the structure of a breastfeeding support group. Group A only used two media in Activity II: an e-poster and an 
exclusive breastfeeding calendar. In comparison with Group A, Activity II by Group B was better prepared in consolidation with the village government, media, and human resources to form more structure for the breastfeeding support group volunteers. Nevertheless, the media used by Group A were more creative and interesting.

Fauziyyah (2018) conducted a study on the effectiveness of media to increase mothers' knowledge and attitudes towards complementary food in Kenep village, Sukoharjo District. Similarly, the findings of this study showed there was an increase in maternal knowledge after nutrition education carried out by distributing leaflets to $10.2 \%$, pocketbooks to $10.3 \%$, and videos to $18 \%$.

Suhertusi, Desmiwarti, and Nurjasmi (2015) found that respondents who watched health-promotion films had a higher average increase in personal knowledge than respondents who received leaflets $(P=0.001)$. Therefore, the success of information delivery is influenced by the right methods and media. Methods and media that convey interesting language will more positively affect message delivery. Creative health-promotion media can make abstract and difficult concepts more understandable (Suhertusi, Desmiwarti, and Nurjasmi, 2015).

Group B had breastfeeding support group volunteers and promotional materials to assist in breastfeeding practices. Breastfeeding support group volunteers helped health workers in the village and were expected to provide strong support to the mothers. The volunteers would plan, organize, implement, and control activities. In a similar way, the Muhammadiyah Klaten breastfeeding support group in 2015 provided care and conducted training for the supporters who could transmit awareness, commitment, willingness, knowledge, skills, and enthusiasm to community members (Sutaryono and

Purwaningsih, 2015). An exclusive breastfeeding support group is an effective way to sustain breastfeeding.

Unlike Group B, which used two activities, Group A had three activities. Activity III of Group A was a follow-up to Activity II (monitoring and evaluation of the exclusive breastfeeding calendar). Activity III sought to discover whether a calendar helped mothers to increase the frequency of everyday breastfeeding, ideally every two hours or 8 to 12 times a day. Activity III was carried out for one week with the volunteers making two visits to the breastfeeding mothers' homes, usually on the third and sixth days. The initiators of the breastfeeding support group in Activity III put stickers on each door to reward the mothers who reached an ideal breastfeeding frequency in a day.

Group B monitored Activity III by looking at how breastfeeding mothers used the pocketbook. Breastfeeding reminders could make mothers more motivated to increase the frequency of breastfeeding for their babies. Research on professional breastfeeding support for first-time mothers states that early professional breastfeeding support, especially weekly telephone support, significantly increased the rates of exclusive breastfeeding in the early postnatal period and the overall duration of breastfeeding across the first six months (Fu et al., 2014). Compared to standard support groups, $60 \%$ of participants receiving professional telephone support were more than twice as likely to breastfeed exclusively during the first month postpartum.

During the first six months, participants receiving professional telephone support were $20 \%$ less likely to stop breastfeeding compared to the standard support group (Fu et al., 2014). Providing mothers with personal telephonebased peer support for breastfeeding during the first six months postpartum was an effective intervention to maintain 
breastfeeding in the community (Forster et al., 2019). This confirmed that continuous intervention could change behavior. Rayfield, Oakley, and Quigley (2015) found that breastfeeding support was more likely to be effective if it was proactive, delivered face-to-face, and provided on an on-going basis.

The results show that the intervention in Group B uses better informative media and better advance preparation compared with the intervention in Group A. Group A, however, made and used calendar media more effectively than other media.

Both programs evaluated the frequency of breastfeeding with a homevisit method and printed media as an everyday reminder. However, the duration of the intervention in each meeting was different. Once both groups had formed breastfeeding support group volunteers, the volunteers will assist and monitor breastfeeding frequency (Group B). While Group A only received a guidebook that contained myth-fact information about exclusive breastfeeding.

\section{Program Success Analysis}

Success can be measured in two ways: first, by setting goals or targets and then comparing the accomplished activity to the goal. A successful program can be evaluated by seeing how many indicators were achieved under the plan.

Table 3 shows that Group A has five indicators, while Group B has seven. The indicators show the program's success at $\geq 80 \%$. When they were accumulated, the indicator success in Group A was $80 \%$ (four of five indicators were achieved), while in Group B, it was $85.71 \%$ (six of seven indicators were achieved). Thus, Group B has a higher indicator of success than Group A.

When analyzing the strengths and weaknesses of both programs, it can be recognized that Group A had more active participants, more creative media, and

more innovative and interesting theoretical materials. However, the village government in Group A had poor communication with basic support group and lack of funding. Furthermore, they did not participate in improving exclusive breastfeeding behavior. Whereas, Group A analyzed general characteristics, the community only but not prospective volunteers. The intervention in Group A focuses on pregnant and breastfeeding women, not empowered volunteers.

Even though Group B had a lower budget for the program, they could managed it efficiently. They also used the budjet for forming a breastfeeding support group program. They also analyzed characteristics of prospective volunteers and addressed the intervention focusing on their readiness and skills. However, the Group B weaknesses included less attractive media and passive breastfeeding mothers' participation.

From the analysis of strengths and weaknesses, Group B received more material and physical support, such as human resources. Even commitment of breastfeeding support group in health care facilities, such as families, health workers, and the village government also supported the breastfeeding program in Group B.

The percentage of the success indicator in Group B was higher than in Group A; thus, the intervention in Group B was more effective. Group B used many resources: human resources, financial resources, and material resources. Human resources were an important component that influenced the effectiveness of community empowerment programs and alternatives for health probelms in both Groups A and B.

Community empowerment can improve the quality of human resources, especially in shaping and changing the behavior of the community to achieve a higher level of overall health. Thus, the policies and commitments are important 
and influence the interventions on many targets. The existence of policies can help facilitate an effective coordination system to change people's behavior.

Table 3. The Comparison of Program Success in Group A and Group B.

\begin{tabular}{|c|c|}
\hline \multicolumn{2}{|c|}{ Program Success } \\
\hline Group A & Group B \\
\hline "Be Ready to Exclusively Breastfeeding & Exclusive Breastfeeding Fun Sharing session \\
\hline$D E S A S I)$ & 1.The attendance of participants in the program \\
\hline $\begin{array}{l}\text { 1. Participants' attendance was } 72 \% \\
\text { from the target of } 50 \% \text { (achieved). }\end{array}$ & $\begin{array}{l}\text { was } 25 \% \text {, under the target of } 50 \% \text { (not } \\
\text { achieved) }\end{array}$ \\
\hline $\begin{array}{l}\text { 2. The percentage of participants who } \\
\text { achieved a high post-test score was } \\
63 \% \text { (not achieved). }\end{array}$ & $\begin{array}{l}\text { 2. The increasing attitude of participants towards } \\
\text { exclusive breastfeeding was } 18.75 \% \text {, above } \\
\text { the target of } 15 \% \text { (target achieved) }\end{array}$ \\
\hline $\begin{array}{l}\text { 3. Thirty percent of participants } \\
\text { conducted questions and answers } \\
\text { (reached). }\end{array}$ & \\
\hline $\begin{array}{l}\text { One Fun Day with breastfeeding support } \\
\text { group }\end{array}$ & $\begin{array}{l}\text { Exclusive breastfeeding support group Session } \\
\text { I (Keping/Kelompok Pendamping I) }\end{array}$ \\
\hline $\begin{array}{l}\text { Providing approval sheets and } \\
\text { attaching exclusive breastfeeding } \\
\text { family stickers reached }>30 \% \\
\text { (achieved) }\end{array}$ & $\begin{array}{l}\text { The membership and structure of the } \\
\text { exclusive breastfeeding support group } \\
\text { volunteers required at least ten volunteers } \\
\text { (achieved) }\end{array}$ \\
\hline & $\begin{array}{l}\text { 2. Volunteers' knowledge and skills in } \\
\text { assisting target mothers (pregnant women and } \\
\text { mothers breastfeeding from birth to six } \\
\text { months) increased by } 10 \% \text { (achieved) }\end{array}$ \\
\hline & $\begin{array}{l}\text { 3. Obtained commitment for an exclusive } \\
\text { breastfeeding support group to facilitate all } \\
\text { activities increased by } 80 \% \text { (target achieved) }\end{array}$ \\
\hline & $\begin{array}{l}\text { 4. A letter of support for the exclusive } \\
\text { breastfeeding support group volunteers from } \\
\text { the village head was issued (achieved) }\end{array}$ \\
\hline & $\begin{array}{l}\text { 5. Modules and pocketbooks for exclusive } \\
\text { breastfeeding support group volunteers were } \\
\text { compiled (achieved) }\end{array}$ \\
\hline Monitoring and Evaluation & Exclusive breastfeeding support group Session \\
\hline $\begin{array}{l}\text { The number of participants who wanted } \\
\text { to be a part of the exclusive breastfeeding } \\
\text { Family was }>30 \% \text { (achieved) }\end{array}$ & $\begin{array}{l}\text { II (Keping/Kelompok Pendamping II) } \\
\text { None }\end{array}$ \\
\hline
\end{tabular}

In implementing Activity II, Group A used an individual approach. Individual approaches require more energy to visit each target (breastfeeding mother), while Group B used a group approach and an individual approach

(exclusive breastfeeding support group). 


\section{[DJAKI \\ IURNAL ADMINISTRAS
KESHATAN INDONESI \\ CONCLUSION}

The analysis of the community's characteristics in Sugihwaras (Group A) and Sumbergede villages (Group B) showed similarities in education level, occupation, and gender. Groups A and B were dominated by junior and senior high school graduates. Occupations in Groups A and $B$ were primarily farmers, farmworkers, and employees of private companies.

The genders in both groups were balanced (50:50). Understanding a community's characteristics will help to prepare the planning of intervention programs.

Group A more frequently met the participants (4:3) when compared to Group $B$. The average duration of activities in both Groups A and B was roughly the same with a five-minute difference. The village government for Group B participated in forming a breastfeeding support group structure and fostering the volunteers. Therefore, Group B (Sumbergede) was better prepared to conduct the program than was Group A (Sugihwaras).

The percentage of achievement in Group B was $85.71 \%$, which was $5.71 \%$ higher than Group A (80\%); Group B had more success and resource power. The intervention program for Group B (Sumbergede) was more effective and had a higher potential to become a sustainable program in subsequent years.

The researchers hope that the intervention program in Group B can be an alternative solution for other regions with the same challenges. To achieve successful exclusive breastfeeding, resources, sustainable and continuous commitment and support from government, community, and colleagues are required.

\section{ACKNOWLEDGMENT}

This study was supported by a Field Work Project report from Group 14 and 15

2017/2018, Faculty of Public Health, Universitas Airlangga

\section{CONFLICT OF INTEREST}

The authors state that there is no conflict of interest in this article.

\section{REFERENCES}

Bojonegoro District Health Office (2017) The Bojonegoro District Health Profile Data in 2017. Bojonegoro.

Bosnjak, A. P. et al. (2009) 'Influence of sociodemographic and psychosocial characteristics on breastfeeding duration of mothers attending breastfeeding support groups', Journal of Perinatal Medicine, 37(2), pp. 185-192. doi: 10.1515/JPM.2009.025.

Crossland, Ni. et al. (2016) 'Breast Pumps As An Incentive For Breastfeeding: A Mixed Methods Study Of Acceptability', Maternal and Child Nutrition, 12(4), pp. 726-739. doi: $10.1111 / \mathrm{mcn} .12346$.

Cusick, S. and Georgieff, M. K. (no date) The First 1,000 Days of Life: The Brain's Window of Opportunity, UNICEF Office of Research. Available at: https://www.unicefirc.org/article/958-the-first-1000days-of-life-the-brains-window-ofopportunity.html (Accessed: 4 October 2019).

Fauziyyah, F. I. N. (2018) Efektivitas Penggunaan Media untuk Meningkatkan Pengetahuan dan Sikap lbu Tentang Makanan Pendamping ASI (MP-ASI) di Desa Kenep Kabupaten Sukoharjo. Undergraduate Thesis. Universitas Muhammadiyah Surakarta.

Februhartanty, J. et al. (2012) 'Profiles of Eight Working Mothers Who Practiced', Breastfeeding Medicine Journal, 7(1), pp. 54-59. doi: 
10.1089/bfm.2011.0017.

Forster, D. A. et al. (2019) 'Proactive Peer (Mother-to-Mother) Breastfeeding Support by Telephone (Ringing up About Breastfeeding Early [RUBY]): A Multicentre, Unblinded, Randomised Controlled Trial', EClinicalMedicine, 8, pp. 20-28. doi: 10.1016/j.eclinm.2019.02.003.

Fu, I. C. Y. et al. (2014) 'Professional breastfeeding support for first-time mothers: A multicentre cluster randomised controlled trial', BJOG: An International Journal of Obstetrics and Gynaecology, 121(13), pp. 1673-1683. doi: 10.1111/14710528.12884

Hajeebhoy, N. (2016) The Lancet Breastfeeding Series. Geneva. Available at: https://www.who.int/nutrition/events/ 2016_bfhi_congress_presentation_la testscience_nemat.pdf?ua $=1$.

Indonesian Ministry of Health (2016) General Guidelines For A Healthy Indonesia Program With A Family Approach. Jakarta: Indonesian Ministry of Health,. Available at: http://www.depkes.go.id/resources/d ownload/lain/Buku.

Nurrohmah, A., Prawitasari, S. and Nisman, W. (2015) 'Role of mother support group (KP-lbu) on behavior of exclusive breastfeeding in work area primary health care (Puskesmas) of Ngoresan Surakarta', International Journal of Research in Medical Sciences, 3(Suppl 1), pp. S85--S91. doi: 10.18203/2320-6012.ijrms20151526.

Purwanti, Y. (2015) 'Korelasi Partisipasi Ibu Menyusui pada Kelompok Pendamping ASI dengan Keberhasilan Pemberian ASI Eksklusif', Jurnal Kebidanan dan Keperawatan, 11(1), pp. 73-82.

Raffle, H. et al. (2011) Factors That Influence Breastfeeding Initiation And
Persistence In Ohio's Appalachian Region. Athens. Available at: https://www.ohio.edu/voinovichschoo I/upload/Breastfeeding-in-the-OhioAppalachian-Region.pdf.

Rayfield, S., Oakley, L. and Quigley, M. A. (2015) 'Association between breastfeeding support and breastfeeding rates in the UK: a comparison of late preterm and term infants', BMJ open, 5(11), pp. 1-10. doi: 10.1136/bmjopen-2015-009144.

Silbert-Flagg, J., Balbier, E. and Blakey, C. (2016) 'Impact of Mother's Breastfeeding Support: Lactation Support Provided in a Group Setting', Journal of Pregnancy and Child Health, 3(274). doi: 10.4172/2376127x.1000274.

Sri, A., Judistiani, T. D. and Indra, S. A. (2016) 'Evaluasi Pembentukan dan Pelatihan Kelompok Pendukung ASI di Desa Mekargalih dan Cipacing Kecamatan Jatinangor Kabupaten Sumedang', Jurnal Kebijakan Kesehatan Indonesia, 5(2), pp. 8185.

Subagyo, A. (2016) Hubungan Pelaksanaan Kelompok Pendukung Ibu dengan Tingkat Pengetahuan Ibu dan Praktek Pemberian Air Susu Ibu Eksklusif. Graduate Thesis. Universitas Sebelas Maret Surakarta. Suhertusi, B., Nurjasmi, D. and Nurjasmi, E. (2015) 'Pengaruh Media Promosi Kesehatan tentang ASI Eksklusif terhadap Peningkatan Pengetahuan Ibu di Puskesmas Lubuk Begalung Padang tahun 2014', Jurnal Kesehatan Andalas, 4(1), pp. 17-22. Susilo, J., Kurdant, W. and Siswati, T. (2012) 'Hubungan Program Kelompok Pendukung lbu terhadap Pengetahuan dan Praktik Pemberian ASI Eksklusif', Gizi Indonesia, 35(1), pp. 30-40.

Sutaryono and Purwaningsih, E. (2015) 'Pembentukan Kelompok Pendukung 
Air Susu Ibu (ASI) Muhammadiyah Klaten', in The 2nd University Research Coloquium 2015. Semarang: Lembaga Penelitian dan Pengabdian kepada Masyarakat Universitas Muhammadiyah Semarang, pp. 383-387. Available at:

https://jurnal.unimus.ac.id/index.php/ psn12012010/article/view/1614/1666

Wati, N. H. and Muniroh, L. (2018) 'Pengaruh Kelompok Pendukung Air Susu Ibu (Kp-Asi) Terhadap Perilaku Pemberian Asi Eksklusif Dan Status Gizi Bayi 6-12 Bulan', Media Gizi Indonesia, 13(1), pp. 33-40. doi: 10.20473/mgi.v13i1.33-40.

World Health Organization (2019) 'Ten steps to successful breastfeeding'. World Health Organization, pp. 1-3.

Available at: https://www.who.int/nutrition/bfhi/tensteps/en/ (Accessed: 4 October 2019).

Yunianti, B., Rofi'ah, S. and Rubiyanti (2017) 'Efektivitas Kelompok Pendukung ASI (KP-ASI) Eksklusif terhadap Perilaku Pemberian ASI Eksklusif', Jurnal IImiah Bidan, 2(1), pp. 48-54. 